Arch. Tierz., Dummerstorf 48 (2005) 3, 209-218

Aus dem Institut für Tierzucht und Vererbungsforschung der Stiftung Tierärztliche Hochschule Hannover

OTTMAR DISTL

\title{
The use of molecular genetics in eliminating of inherited anomalies in cattle
}

\author{
Dedicated to Prof. Dr. Detlef Leonhard Simon on the occasion of his $75^{\text {th }}$ birthday
}

\begin{abstract}
Genetic improvement programmes in cattle have significantly contributed to the large increase in milk and meat production. As along with these breeding schemes top ranking AI sires are widely used and in the case, if these sires are carriers of mutated alleles, inherited defects can be widely disseminated. Most of the about 350 inherited anomalies in cattle occur at very low to low frequencies and thus, carriers are usually not detected in progeny tests based on reporting calves with congenital malformations. The molecular genetic decipherment of inherited anomalies is the necessary prerequisite for an efficient prevention of the dissemination of undesired alleles. The paper gives a survey on inherited anomalies being already characterized in cattle with molecular genetic methods. Furthermore, two genetic anomalies, namely congenital X-linked ectodermal dysplasia with hypotrichosis and missing teeth and bilateral convergent strabismus with exophthalmus are described in more detail.
\end{abstract}

Key Words: cattle, inherited anomaly, gene mutation, ectodermal dysplasia, strabismus

\section{Zusammenfassung}

Titel des Beitrages: Die Anwendung von molekulargenetischen Methoden zur Eliminierung von Erbfehlern beim Rind

Die modernen Zuchtprogramme beim Rind haben zu einer wesentlichen Steigerung von Milch- und Mastleistung beigetragen. Da im Rahmen dieser Zuchtprogramme die besten Bullen sehr intensiv eingesetzt werden, besteht auch die Gefahr, dass für Erbfehler unerkannte Anlageträger weit verbreitet werden, und dadurch vermehrt Tiere mit solchen Erbdefekten geboren werden. Da die meisten der ca. 350 beim Rind beschriebenen Erbfehler nur in einer geringen Frequenz auftreten, ist es nicht möglich, über Nachkommentests Anlageträger frühzeitig mit einer hohen Sicherheit zu ermitteln. Deshalb stellt die molekulargenetische Aufklärung von Erbfehlern die notwendige Voraussetzung dar, um die Verbreitung von Defektallelen verhindern zu können. In dem Beitrag wird ein Überblick über die bisher vollständig oder annähernd aufgeklärten genetisch bedingten Anomalien gegeben. Weiterhin werden zwei Erbfehler, nämlich die X-gekoppelte ektodermale Dysplasie mit Hypotrichose und Hypodontie sowie das beidseitige konvergierende Schielen mit Exophthalmus näher beschrieben.

Schlüsselwörter: Rind, Erbfehler, Genmutation, ektodermale Dysplasie, Strabismus

\section{Introduction}

Genetic improvement programmes in cattle have significantly contributed to the large advances in milk and meat production over the past 50 years. Traits that are mainly selected on in industrial countries are milk performance, type traits, weight gain, and carcass traits. In some countries also fertility, longevity and health traits have been added as selection criteria within the last 10-20 years. Most of these traits are under control of many genes and influenced by environmental factors. Therefore, selection has been based on the observable phenotypes and on the prediction of breeding values. 
These selection procedures were applied in large scale without any detailed knowledge of the number of genes involved in the expression of the trait, let alone of the effects of these genes on the trait of the breeding objective or their pleiotropic and linked actions on other traits. The usefulness of this approach has been shown for example by the high rates of improvements in average milk production per lactation in many dairy cow populations. Additionally, in such breeding schemes it is possible that top ranking AI sires which are widely used are carriers of mutated alleles. Even if they are phenotypically normal, they significantly contribute to the dissemination of inherited anomalies. Progress made in molecular genetic analysis can help to identify causal mutations of anomalies manifesting at birth or later in life and to find closely linked markers or even better to unravel the causal mutations for genetic loci causing these phenotypes. Using these new developments in animal breeding the wide spreading of genes causing anomalies can be prevented. In the case that these undesired alleles have been detected with molecular genetic methods, animals can be diagnosed through genotyping as carriers of alleles with deleterious effects on function of organs. By means of the molecular genetic approaches along with the models of the population genetics, loci of the cattle genome important for inherited anomalies can be characterized and exploited for reduction of inherited anomalies and elimination of defective alleles. The purpose of this paper is to give an overview on the present knowledge of molecular genetic characterization of genes controlling inherited anomalies and to show how this information can be used to avoid the dissemination of deleterious alleles through heavily used AI bulls.

\section{Genetic models underlying inherited anomalies}

Qualitative genetic traits in genetic theory are determined by single genes segregating in Mendelian fashion. Further development of statistical methods for segregation analysis of pedigrees allowed include besides a single gene polygenic effects and nongenetic environmental factors in the analysis. Employing such models has shown that single genes are very often modified in their effects on traits by many additional small gene effects. Therefore, such genes are called major genes and they may play an important role in qualitative traits.

Many of the inherited anomalies were characterized as qualitative genetic traits only influenced by a single locus or even not more than two or three different loci. Allelic and non-allelic heterogeneity also plays an important role in the genetic determination of anomalies, as different genes are involved in different breeds.

Molecular genetic analysis can now help to identify the genes responsible for inherited anomalies. Two broadly different types of genetic loci that can be genotyped by means of molecular genetic methods can be distinguished: causal mutations of genes responsible for expression of qualitative traits or mutations of genes being associated with quantitative or qualitative traits, non-functional mutations that are linked to genes being involved in expression of traits of interest. These non-functional mutations are abundant across the whole genome and thus, represent anonymous markers for all types of phenotypic traits. Using anonymous markers the whole genome or chromosomal regions of the genome can be scanned for significant cosegregation with the trait phenotype.

The best method for finding mutations of genes is to determine the genomic DNA sequence directly or cDNA sequence using RT-PCR (reverse transcriptase polymerase 
chain reaction) for the RNA. The first approach to do this was the development of restriction fragment length polymorphisms. The disadvantage of this method is that only those base pair exchanges can be detected which are specific for restriction enzymes. Along with improved DNA sequence methods many single nucleotide polymorphisms (SNPs), which are characterized by the exchange of a single base pair, were detected. The density of SNPs in the eukaryotic genomes is very high. Each 1000 base pairs a SNP is expected. A further very often observed type of DNA variation is caused by variable number of tandem repeats of DNA elements. These repetitive DNA elements can consist of very short DNA motifs (1-5 base pairs: microsatellites) or 6100 nucleotides (minisatellites) or even larger DNA elements (satellites). The most common repetitive DNA motifs in cattle are microsatellites with a repeat of the dinucleotide CA/GT. The frequency in the whole genome in cattle is estimated to be about 45,000, whereby about 10,000 may be suited as highly polymorphic markers. Microsatellites can be visualized by using polymerase chain reaction (PCR) with flanking primers and gel electrophoresis.

\section{Identification of trait genes}

Genome analysis makes it possible to gain knowledge of the genetic architecture of traits. Four major strategies to characterize trait loci can be used. The classical way to identify genes can be based on previous biochemical analysis of the gene product. In this case the biochemical pathway involved has to be known and the inheritance has to be proven. The second approach used refers to candidate genes. Candidate genes may be chosen on the basis of their known physiological or biochemical function. More often candidate genes may be analysed, because these genes are already characterized and cloned in other species like man, mouse or rat and mutations in these genes control a phenotype with striking similarities. Positional cloning is used when a trait locus has been mapped to a chromosomal region by linkage analyses using microsatellites or SNPs. The chromosomal region in question should be identified as precisely as possible. After that the genomic region will be cloned and the transcripts of the genes in this region identified. Then these genes can be screened for association with the phenotypic trait or candidate genes identified and after having found possible causal genes these are investigated for possible mutations. This approach was often a demanding task in the past, but with the increasing amount of cattle genome sequences available, candidate regions can now more easily screened. Narrowing the candidate region to $1 \mathrm{cM}$ means that about $1 \mathrm{Mb}$ has to be sequenced and about 20-30 genes have to be screened. An alternative approach is therefore, to map first the trait locus and then to look for candidate genes assigned to that particular chromosomal region. The strategy is denoted as positional candidate cloning which was shown to be a very useful approach. Mapping information from other species can be exploited to find appropriate candidate genes. Coding sequences are often well conserved even between distantly related species. This approach in combination with comparative genomics makes it possible to identify homologous chromosome segments between species and by using the regions of conserved synteny to the human or mouse genome. Homologous gene loci can be accessed and the most promising candidate genes can be selected for molecular genetic analysis. Once a putative trait gene has been mapped and identified, sequence analysis is employed to characterize the gene and to search for mutations. Having identified putative mutations, then it is necessary to provide 
evidence that the mutation causes the trait value or its significant association with the expression of the trait. This can be well accomplished if families or lines are available segregating for the trait under investigation. Strong indication for a causal relationship may also be provided if a mutation causes a substitution, deletion or insertion of an amino acid, particularly, in a highly conserved and functionally important part of the protein.

\section{Molecular genetic characterization of inherited anomalies}

A survey on inherited anomalies being already characterized with molecular genetic methods in cattle is given in the Table. Positional candidate cloning and candidate gene approaches using genome information from man and mouse were most often used to unravel the causal mutations of genes responsible for inherited anomalies. Identification of the causal mutation(s) allows to perform planned matings or to exclude heterozygote carrier animals from breeding. The number of inherited Mendelian defects in cattle was estimated at about 350. In comparison to the known visible inherited anomalies in cattle, only for a very small number of inherited defects the causal mutation could be detected. For some inherited disorders a genomic region could be identified. The length of these regions of chromosomes that are linked to the inherited defect is typically less than 3-5 cM, but the exact position of the causal gene is unknown. In this case selection can be based on the close linkage between flanking markers and the putative gene locus for the inherited defect. The efficiency of selection may be lowered because linkage phases between the markers and the putative causal gene locus will not be the same in all families and must, therefore, be reestimated on a within-family basis. Carriers which are not related to affected animals cannot be identified or only with a low probability using flanking markers. A further problem is encountered with the application of marker based genetic tests. The more successfully carriers are eradicated, the faster the power of the marker test decreases.

Table

Molecular genetic diagnosis for inherited anomalies in cattle (Molekulargenetische Diagnose von Erbfehlern beim Rind)

\begin{tabular}{lll}
\hline Anomaly & Breed & Reference \\
\hline Anhidrotic ectodermal dysplasia & Holstein Friesian & DRÖGEMÜLLER et al., \\
& & 2001 \\
Bovine leukocyte adhesion deficiency (BLAD) & Holstein Friesian & SHUSTER et al., 1992 \\
$\begin{array}{l}\text { Chediak-Higashi syndrome } \\
\text { Chondrodysplastic dwarfism }\end{array}$ & Japanese Black & KUNIEDA et al., 1999 \\
$\begin{array}{l}\text { Chronic interstitial nephritis with diffuse zonal } \\
\text { fibrosis (CINF) }\end{array}$ & Japanese Brown & TAKEDA et al., 2002 \\
$\begin{array}{l}\text { Citrullinemia } \\
\text { Complex Vertebral Malformation }\end{array}$ & Holstein Friesian & HIRANO et al., 2000 \\
\hline
\end{tabular}




\begin{tabular}{|c|c|c|}
\hline Table continued (Fortsetzung der Tabelle) & & \\
\hline $\begin{array}{l}\text { Deficiency of uridine monophosphate synthase } \\
\text { (DUMPS) }\end{array}$ & Holstein Friesian & $\begin{array}{l}\text { SCHWENGER et al., } \\
1993\end{array}$ \\
\hline Ehlers-Danlos Syndrome (dermatosparaxis) & Holstein Friesian & TAJIMA et al., 1999 \\
\hline $\begin{array}{l}\text { Ehlers-Danlos syndrom, type VII } \\
\text { (dermatosparaxis) }\end{array}$ & Holstein Friesian & COLIGE et al., 1999 \\
\hline Glycogen storage disease II & Shorthorn, Brahman & PALMER et al., 1994 \\
\hline Glycogen storage disease $\mathrm{V}$ & Charolais & TSUJINO et al., 1996 \\
\hline Goitre & Afrikander & RICKETTS et al., 1985 \\
\hline$\alpha$-Mannosidosis & Angus, Galloway & $\begin{array}{l}\text { TOLLERSRUD et al., } \\
1997\end{array}$ \\
\hline Maple syrup urine disease & $\begin{array}{l}\text { Polled Hereford, } \\
\text { Polled Shorthorn }\end{array}$ & ZHANG et al., 1990 \\
\hline Muscular hypertrophy & $\begin{array}{l}\text { Belgian Blue, Limousin, } \\
\text { Piedmontese, etc. }\end{array}$ & GROBET et al., 1997 \\
\hline Myoclonus & Hereford & PIERCE et al., 2001 \\
\hline Ocular disorder $(*)$ & Local Japanese Black & IHARA et al., 2005 \\
\hline Protophorphyria & $\begin{array}{l}\text { Blonde d'Aquitaine, } \\
\text { Limousin }\end{array}$ & JENKINS et al., 1998 \\
\hline Renal dysplasia & Japanese Black & OHBA et al., 2000 \\
\hline Spherocytosis & Japanese Black & INABA et al., 1996 \\
\hline Spinal dysmyelination $(*)$ & Brown Swiss, Brown Cattle & NISSEN et al., 1999, 2001 \\
\hline Spinal muscular atrophy $(*)$ & Brown Swiss, Brown Cattle & FÖRSTER, 2001 \\
\hline Syndactyly (*) & Holstein Friesian & CHARLIER et al., 1996 \\
\hline Umbilical hernia & Israeli Holstein & RON et al., 2004 \\
\hline Weaver syndrome $(*)$ & Brown Swiss, Brown Cattle & GEORGES et al., 1993 \\
\hline
\end{tabular}
$\left.{ }^{*}\right)$ Only marker test, the responsible gene is not yet known.

\section{Congenital $\mathrm{X}$-linked hypotrichosis with anodontia}

Congenital X-linked hypotrichosis with missing teeth is a rarely observed lethal anomaly in cattle (DRIEUX et al., 1950). This phenotype shows striking similarities to the human X-linked anhidrotic ectodermal dysplasia. An X-linked recessive mode of inheritance was shown for a pedigree of black pied German Holsteins with four affected male calves exhibiting a generalized hypotrichosis, hypodontia and absence of eccrine nasolabial glands (DISTL et al., 2000a). A further case was observed in a 
family of red pied German Holsteins. The symptoms were hypotrichosis, nearly complete anodontia, a reduced number of sweat glands, and absence of eccrine nasolabial, tracheal and bronchial glands (DRÖGEMÜLLER et al., 2003). A scan of the $\mathrm{X}$-chromosome identified an identical-by-descent genomic region on the long arm of the X-chromosome. Thus the X-chromosomal ectodysplasin (ED1) gene located at HSX12q-q13.1 was chosen as candidate gene (DISTL et al., 2000b). The subsequent cloning and mutation analysis revealed that in the black pied German Holstein family exon 3 and flanking parts of both introns were deleted in affected males and in one copy of the X-chromosome of female carriers. This deletion caused a frameshift resulting in a truncated protein and lacking the collagen-like trimerization and TNFlike (tumor necrosis factor) signalling domain of ectodysplasin A1 and A2 proteins (DRÖGEMÜLLER et al., 2001). In the red pied German Holstein family a point mutation in the downstream 5'-splice site of intron 8 appeared responsible for the phenotype. The mutation changed the canonical GT dinucleotide at the beginning of the $5^{\prime}$-splice sequence into GG. The consequence of this mutation was an incorrect splicing of the $5^{\prime}$-end of intron 8 and $3^{\prime}$-end of intron 7. The resulting mRNA in the affected calf lacked 51 or 45 bp with respect to the ED1-A1 or ED1-A2 transcript (DRÖGEMÜLLER et al., 2002). The mutations observed in these two German Holsteins families were associated with large deletions of the transcripts and ectodysplasin protein and resulted in loss of function mutants. The bovine ectodermal dysplasia phenotype may also serve as a model for exploring ectodysplasin action in man and other species.

\section{Bilateral convergent strabismus with exophthalmus (BCSE)}

Bilateral convergent strabismus with exophthalmus (BCSE) is a heritable eye defect, which is prevalent in many cattle breeds and known worldwide. BCSE shows a progressive course and ends up in complete blindness. The onset of the defect can sometimes be late in life and often first signs of the defect are not noticed prior to first breeding. Generally, no signs of the defect are present at birth. According to HOLMES and YOUNG (1957), the earliest manifestation of the defect is usually at the age when the heifers are in calf and often not until after calving, although those investigators also report one calf affected at birth. First symptoms of BCSE were found in cattle at least one year old by GERST and DISTL (1997 and 1998), who also found it impossible to ascertain an age limit after which all affected animals would have started showing symptoms of BCSE. The condition generally shows a progressive course that advances at an individual speed, which may be interrupted by long, apparently stable periods (HOLMES and YOUNG, 1957). The incidence of BCSE in German Brown cattle was estimated by GERST and DISTL (1997) to be 0.9 in adult cows and $0.1 \%$ in young animals. Due to the smaller amount of data for the breeds German Holsteins and German Fleckvieh, only tendencies for incidences were estimated for these breeds. However, the incidence of BCSE in German Holsteins seemed to be higher and that of German Fleckvieh lower than in German Brown cattle. There were different modes of inheritance proposed for BCSE, but an autosomal dominant major gene was most likely in German Brown cattle (DISTL, 1993). Associations with milk production traits could not be found (DISTL and GERST, 2000). Progressive external ophthalmoplegia (PEO) in man has striking similarities to BCSE in cattle. PEO refers to a group of disorders characterised by ptosis and slowly progressive bilateral 
immobility of the eyes, and is considered to be the most frequent form of mitochondrial encephalomyopathies in man (SORKIN et al., 1997). In many cases the onset of the disease is in adolescence or adulthood. Based on age of onset and severity of clinical symptoms, patients with PEO are divided into three groups. The most severe variant is called Kearns-Sayre syndrome and is characterised by an infantile, childhood or adolescent onset. The second is the milder, chronic PEO with an adolescent or adult onset. The third is isolated chronic PEO with an adult onset and mild symptoms. PEO are monogenic autosomal dominant (adPEO) or autosomal recessive (arPEO) defects caused by mutations of different genes. For polymerase (DNA directed), gamma (POLG) autosomal dominant and recessive mutations were found (VAN GOETHEM et al., 2001), whereas for solute carrier family 25, member 4 (SLC25A4) (KAUKONEN et al., 2000; NAPOLI et al., 2001; KOMAKI et al., 2002) and progressive external ophthalmoplegia 1 (PEO1, chromosome 10 open reading frame 2, C10orf2) (SPELBRINK et al., 2001) the mutations were only autosomal dominant. Since the proteins encoded by these genes are required for replication or repair of the mitochondrial genome or catalytic processes in the mitochondria, defects in these genes will cause mtDNA loss or deletion, which leads to tissue dysfunction (SUOMALAINEN and KAUKONEN, 2001). Because of their high energy consumption and dependence on oxidative energy, ocular tissues are affected especially often by mitochondrial defects (MOJON, 2001).

These aforementioned genes with dominantly acting mutations causing PEO in humans were chosen as candidate genes for BCSE in cattle. After localisation of POLG, SLC25A4 and PEO1 (C10orf2) on bovine chromosomes BTA21q17-q22, BTA27q14-q15 and BTA26q13-q21, microsatellite markers were developed and tested for allelic cosegregation with the BCSE phenotype. Neither these markers nor evenly distributed microsatellite markers on the respective bovine chromosomes showed significant linkage with BCSE. Thus, these candidate genes could be excluded as responsible for bovine BCSE. A whole genome scan has to be completed for the BSCE-causing genes to be identified. Comparative genomics can then be used as a very effective approach towards unravelling the genetic basis of bovine BCSE. When the genes with their causal mutations for BCSE are identified, breeding strategies can be developed to eradicate this defect in cattle. Furthermore, new insights may be gained into the causes and pathogenesis of strabismus, possibly leading to therapeutic measures.

\section{Conclusions}

Diagnosis and reporting of anomalies and diseases to centralized data bases or institutions by the veterinary practitioner, farmer and breeding organization is a very important task. This information will be often the seed for molecular genetic analyses to identify the causal mutations of genes. Collection of phenotypic data and blood samples of animals affected with anomalies, their parents and further relatives are the further most important prerequisites for a molecular genetic analysis. The molecular genetic techniques are now available to characterize genes responsible for inherited monogenic or oligogenic defects in cattle. The number of inherited anomalies, which are identified on the molecular level, will be expected to increase in the next years. The mutation tests for genes responsible for inherited anomalies will be exploited in breeding programmes and are also useful for breeding animals on farms. The genetic 
diagnosis of anomalies has great implications for breeders and breeding organizations because the origin of a deleterious gene may be traced back to widely used sires. Based on a precise genetic diagnosis, recommendations for the farmers and breeders can be given to improve eradication programmes for deleterious alleles.

\section{References}

AGERHOLM, J.S.; BENDIXEN, C.; ANDERSEN, O.D.; ARNBJERG, J.:

Complex vertebral malformation in Holstein calves. J. Vet. Diag. Invest. 13, (2001), 283-289

CHARLIER, C.; FARNIER, F.; BEZI, P.; VANMANSHOVEN, P.; BROUWERS, B.; VROMANS, H.; GEORGES, M.:

Identity-by-descent mapping of recessive traits in livestock: application to map the bovine syndactyly locus to chromosome 15. Genome Res. 6 (1996), 580-589

COLIGE, A.; SIERON, A.L.; LIS, W.; SCHWARZE, U.; PETTY, E.; WERTELECKI, W.; WILCOX, W.;

KRAKOW, D.; COHN, D.H.; REARDON, W.; BYERS, P.H.; LAPIERE, C.M.; PROCKOP, D.J.; NUSGENS, B.V.:

Human Ehlers-Danlos syndrome type VIIC and bovine dermatosparaxis are caused by mutations in the procollagen IN-proteinase gene. Am. J. Hum. Genet. 65 (1999), 308-317

DENNIS, J.A.; HEALY, P.J.; BEAUDET, A.L.; OBRIEN, W.E.:

Molecular definition of bovine argininosuccinate synthetase deficiency. Proc. Natl. Acad. Sci. USA 86

DISTL, O.: (1989), 7947-7951

Analysis of pedigrees in dairy cattle segregating for bilateral strabismus with exophthalmus. J. Anim. Breed. Genet. 110 (1993), 393-400

DISTL, O.; GERST, M.:

Association analysis between bilateral convergent strabismus with exophthalmus and milk production traits in dairy cattle. J. Vet. Med. A 47 (2000), 31-36

DISTL, O.; DRÖGEMÜLLER, C.; KUIPER, C.; KUTSCHKE, L.; HERMANNS, W.; KEHLER, W.; SCHOLZ, H.:

Genetische Untersuchungen von kongenitaler Hypotrichose mit Anodontie bei deutschen Holstein Kälbern. Tierärztliche Umschau 55 (2000a), 72-79

DISTL, O.; DRÖGEMÜLLER, C.; KUIPER, H.; KUTSCHKE, L.; KEHLER, W.; SCHOLZ, H.: Kongenitale Hypotrichose mit Anodontie beim Rind. Der praktische Tierarzt 81 (2000b), 496-503

DRIEUX, H.; PRIOUZEAU, M.; THIÉRY, G.; PRIOUZEAU, M.L.: Hypotrichose congenitale avec anodontie, acérie et macroglossie chez le veau. Rec. Med. Vet. 126 (1950), 385-399

DRÖGEMÜLLER, C.; DISTL, O.; LEEB, T.:

Partial deletion of the bovine ED1 gene causes anhidrotic ectodermal dysplasia in cattle. Genome Res. 11 (2001), 1699-1705

DRÖGEMÜLLER, C.; PETERS, M.; POHLENZ, J.; DISTL, O.; LEEB, T.: A single point mutation within the ED1 gene disrupts correct splicing at two different splice sites and leads to anhidrotic ectodermal dysplasia in cattle. J. Mol. Med. 80 (2002), 319-323

DRÖGEMÜLLER, C.; KUIPER, H.; LEEB, T.; PETERS, M.; POHLENZ, J.; DISTL, O.: Congenital hypotrichosis and oligodontia in cattle (German). Tierärztl. Praxis 31 (2003), 70-76

FÖRSTER, M.:

Wie groß sind die Probleme mit Erbfehlern beim Rind? Züchtungskunde 73 (2001), 434-441

GEORGES, M.; DIETZ, A.B.; MISHRA, A.; NIELSEN, D.; SARGEAUT, L.S.; SORENSEN, A.; STEELE, M.R.; ZHAO, X.; LEIPOLD, H.; WOMACK, J.E.; LATHROP, M.: Microsatellite mapping of the gene causing Weaver disease in cattle will allow the study of an associated quantitative trait locus. Proc. Natl. Acad. Sci. USA 90 (1993), 1058-1062

GERST, M.; DISTL, O.:

Einflüsse auf die Dissemination des bilateralen Strabismus convergens mit Exophthalmus beim Rind. Arch. Tierz., Dummerstorf 40 (1997), 401-412

GERST, M.; DISTL, O.:

Verbreitung und Genetik des bilateralen Strabismus convergens mit Exophthalmus beim Rind. Tierärztliche Umschau 53 (1998), 6-15

GOETHEM, VAN, G.; DERMAUT, B.; LOFGREN, A.; MARTIN, J.J.; VAN BROECKHOVEN, C.: Mutation of POLG is associated with progressive external ophthalmoplegia characterized by mtDNA deletions. Nat. Genet. 28 (2001), 211-212 
GROBET, L.; MARTIN, L.J.R.; PONCELET, D.; PIROTTIN, D.; BROUWERS, B.; RIQUET, J.; SCHOEBERLEIN, A.; DUNNER, S.; MENISSIER, F.; MASSABANDA, J.; FRIES, R.; HANSET, R.; GEORGES, M.:

A deletion in the bovine myostatin gene causes the double-muscled phenotype in cattle. Nat. Genet. 17 (1997), 71-74

HIRANO, T.; KOBAYASHI, N.; ITOH, T.; TAKASUGA, A.; NAKAMARU, T.; HIROTSUNE, S.; SUGIMOTO, Y.:

Null mutation of PCLN-1/Claudin-16 results in bovine chronic interstitial nephritis. Genome Res. 10 (2000), 659-663

HOLMES, J.R.; YOUNG, G.B.:

A note on exophthalmus with strabismus in Shorthorn cattle. Vet. Rec. 69 (1957), 148-149

IHARA, N.; FUJITA, T.; SHIGA, K.; ITOH, M.; WATANABE, T.; SUGIMOTO, Y.:

Linkage analysis reveals two independent loci for ocular disorders in a local Japanese Black cattle population. Anim. Genet. 36 (2005), 132-134

INABA, M.; YAWATA, A.; KOSHINO, I.; SATO, K.; TAKEUCHI, M.; TAKAKUWA, Y.; MANNO, S.;

YAWATA, Y.; KANZAKI, A.; SAKAI, J.; BAN, A.; ONO, K.; MAEDE, Y.:

Defective anion transport and marked spherocytosis with membrane instability caused by hereditary total deficiency of red cell band 3 in cattle due to a nonsense mutation. J. Clin. Invest. 97 (1996), 18041817

JENKINS, M.M.; LEBOEUF, R.D.; RUTH, G.R.; BLOOMER, J.R.:

A novel stop codon mutation (X417L) of the ferrochelatase gene in bovine protoporphyria, a natural animal model of the human disease. Biochimica et Biophysica Acta - Molecular Basis of Disease 1408 (1998), 18-24

KAUKONEN, J.; JUSELIUS, J. K.; TIRANTI, V.; KYTTALA, A.; ZEVIANI, M.; COMI, G.P.; KERANEN, J.;

PELTONEN, L.; SUOMALAINEN, A.:

Role of adenine nucleotide translocator 1 in mtDNA maintenance. Science 289 (2000), 782-785

KOMAKI, H.; FUKAZAWA, T.; HOUZEN, H.; YOSHIDA, K.; NONAKA, I.; GOTO, Y.:

A novel D104G mutation in the adenine nucleotide translocator 1 gene in autosomal dominant progressive external ophthalmoplegia patients with mitochondrial DNA with multiple deletions. Ann. Neur. 51 (2002), 645-648

KUNIEDA, T.; NAKAGIRI, M.; TAKAMI, M.; IDE, H.; OGAWA, H.:

Cloning of bovine LYST gene and identification of a missense mutation associated with ChediakHigashi syndrome of cattle. Mamm. Genome 10 (1999), 1146-1149

MOJON, D.:

Eye diseases in mitochondrial encephalopathies. Therapeutische Umschau 58 (2001), 49-55

NAPOLI, L.; BORDONI, A.; ZEVIANI, M.; HADJIGEORGIOU, G. M.; SCIACCO, M.; TIRANTI, V.;

TERENTIOU, A.; MOGGIO, M.; PAPADIMITRIOU, A.; SCARLATO, G.; COMI, G.P.:

A novel missense adenine nucleotide translocator-1 gene mutation in a Greek adPEO family. Neurology 57 (2001), 2295-2298

NISSEN, P.H.; SHUKRI, N. M.; AGERHOLM, J.S.; FREDHOLM, M.; BENDIXEN, C.: Genetic mapping of spinal dysmyelination in cross-bred American Brown Swiss cattle. Arch. Tierz., Dummerstorf 42 (1999) Special Issue, 170-171

NISSEN, P.H.; SHUKRI, N. M.; AGERHOLM, J.S.; FREDHOLM, M.; BENDIXEN, C.: Genetic mapping of spinal dysmyelination in cross-bred American Brown Swiss cattle to bovine chromosome 11. Mamm. Genome 12 (2001), 180-182

OHBA, Y.; KITAGAWA, H.; KITOH, K.; SASAKI, Y.; TAKAMI, M.; SHINKAI, Y.; KUNIEDA, T.:

A deletion of the paracellin-1 gene is responsible for renal tubular dysplasia in cattle. Genomics 68 (2000), 229-236

PALMER, D. G.; DORLING, P. R.; HOWELL, J. M.:

Bovine glycogenosis type II - The molecular defect in Shorthorn cattle. Neuromuscular Disorders 4 (1994), 39-48

PIERCE, K. D.; HANDFORD, C. A.; MORRIS, R.; VAFA, B.; DENNIS, J. A.; HEALY, P. J.; SCHOFIELD, P. R.:

A nonsense mutation in the alpha 1 subunit of the inhibitory glycine receptor associated with bovine myoclonus. Mol. Cell. Neurosci. 17 (2001), 354-363.

RICKETTS, M. H.; POHL, V.; MARTYNOFF, G.; DEBOYD, C. D.; BESTER, A. J.; JAARSVELD, P. P.; VAN VASSART, G.:

Defective splicing of thyroglobulin gene transcripts in the congenital goitre of the Afrikander cattle. EMBO J. 4 (1985), 731-737

RON, M.; TAGER-COHEN, I.; FELDMESSER, E.; EZRA, E; KALAY, D.; ROE, B.; SEROUSSI, E.; WELLER, J.I.: 
Bovine umbilical hernia maps to the centromeric end of Bos taurus autosome 8. Anim. Genet. 35 (2004), 431-437

SCHWENGER, B.; SCHÖBER, S.; SIMON, D.:

DUMPS cattle carry a point mutation in the uridine monophosphate synthase gene. Genomics 16 (1993), 241-244

SHUSTER, D.E.; KEHRLI M, E.; ACKERMANN, M.R.; GILBERT, R.O.:

Identification and prevalence of a genetic defect that causes leukocyte adhesion deficiency in Holstein cattle. Proc. Natl. Acad. Sci. USA 89 (1992), 9225-9229

SORKIN, J.A.; SHOFFNER, J.M.; GROSSNIKLAUS, H.E.; DRACK, A.V.; LAMBERT, S.R.:

Strabismus and mitochondrial defects in chronic progressive external ophthalmoplegia. Am. J. Ophthal. 123 (1997), 235-242

SPELBRINK, S.M.; LI, F-Y.; TIRANTI, V.; NIKALI, K.; YUAN, Q.P.; TARIQ, M.; WANROOIJ, S.; GARRIDO, R.; BEESON, D.; POULTON, J.; SUOMALAINEN, A.; JACOBS, H. T.; ZEVIANI, M.; LARSSON, C.:

Human mitochondrial DNA deletions associated with mutations in the gene encoding Twinkle, a phage T7 gene 4-like protein localized in mitochondria. Nat. Genet. 28, (2001) 223-231

SUOMALAINEN, A.; KAUKONEN, J.:

Diseases caused by nuclear genes affecting mtDNA stability. Am. J. Med. Genet. 106 (2001), 53-61

TAJIMA, M.; MIYAKE, S.; TAKEHANA, K.; KOBAYASHI, A.; YAMATO, O.; MAEDE, Y.:

Gene defect of dermatan sulfate proteoglycan of cattle affected with a variant form of Ehlers-Danlos syndrome. J. Vet. Int. Med. 13 (1999), 202-205

TAKEDA, H.; TAKAMI, M.; OGUNI, T.; TSUJI, K.; YONEDA, K.; SATO, H.; IHARA, N.; ITOH, T.; KATA,

S.R.; MISHINA, Y.; WOMACK, J.E.; MORITOMO, Y.; SUGIMOTO, Y.; KUNIEDA, T.:

Positional cloning of the gene LIMBIN responsible for bovine chondrodysplastic dwarfism. PNAS 99 (2002), 10549-10554

TOLLERSRUD, O.K.; BERG, T.; HEALY, P.; EVJEN, G.; RAMACHANDRAN, U.; NILSSEN, O.:

Purification of bovine lysosomal alpha-mannosidase, characterization of its gene and determination of two mutations that cause alpha-mannosidosis. Europ. J. Biochem. 246 (1997), 410-419

TSUJINO, S.; SHANSKE, S.; VALBERG, S.J.; CARDINET, G.H.; SMITH, B.P.; DIMAURO, S.:

Cloning of bovine muscle glycogen phosphorylase cDNA and identification of a mutation in cattle with myophosphorylase deficiency, an animal model for McArdle's disease. Neuromuscular Disorders 6 (1996), 19-26

ZHANG, B.; HEALY, P.J.; ZHAO, Y.; CRABB, D.W.; HARRIS, R.A.:

Premature translation termination of the pre-E1-alpha-subunit of the branched chain alpha-ketoacid dehydrogenase as a cause of maple syrup urine disease in Polled Hereford calves. J. Biol. Chem. 265 (1990), 2425-2427

Received: 2005-04-18

Accepted: 2005-04-27

Author's address

Prof. Dr. OTTMAR DISTL

Institut für Tierzucht und Vererbungsforschung, Stiftung Tierärztliche Hochschule Hannover

Bünteweg 17p

30559 HANNOVER

GERMANY

E-Mail: ottmar.distl@tiho-hannover.de 